\title{
GROWTH ON CUT-OVER PULPWOOD FOREST IN ONTARIO
}

\author{
By G. A. Mulloy \\ Forest Service, Department of the Interior
}

T 1920 a survey of conditions obtaining on cut-over pulpwood lands in the Goulais valley, north of Sault Ste. Marie, was made by Messrs. E. F. McCarthy and C. R. Mills, at that time of the former Commission of Conservation, in cooperation with the Spanish River Pulp and Paper Mills, Limited. An estimate of the standing timber, and growth rate, was made, as well as a study of the regeneration.

Seven years later the Research Division of the Forest Service, Depart. ment of the Interior, undertook to resurvey this area, not only to determine whether the predictions of growth made in 1920 had been substantiated, but to establish a system of line-plots throughout the area by means of which it was proposed to keep the area under periodic observation, so that the subsequent development of the forest could be determined. On the basis of the line plot survey, a number of permanent sample plots on which all trees were tagged and measured, were selected so that accurate records of growth can be kept.

These two surveys now provide a means of measuring the actual growth which has taken place during the interval, as well as a check upon the estimates of current growth which were made at the times of each survey.

\section{LOCATION}

\section{Description of Forest}

The Goulais river enters Lake Superior about twenty miles by shore distance from the outlet of Lake Superior at the St. Mary river. The general direction of flow of the river is southwesterly although for the last twenty miles, it is nearly due westerly. The watershed includes an area of 472,000 acres, mostly wooded, but the investigations were confined to two townships or about 40,000 acres near the northern limit of cutting on the watershed, and near the junction of the main Goulais river and its east branch. These townships were selected because sufficient time had elapsed since the date of logging operations to show the influence of cutting on the subsequent development of the forest.

\section{TOPOGRAPHICAL FEATURES}

The greater part of these townships is composed of broad-topped, irregular ridges, having no definite trend, generally with abrupt bluffs facing south and southeast, and more gradual slopes in other directions. The tops of the ridges rise to about 1,700 feet of absolute elevation, or 400 to 600 feet above the general valley level. 
The valleys of the several creeks which drain the area, with the exception of the lower portions of the three larger ones, are steep and narrow, broadening out towards the top of each divide. Coldwater creek has about three miles of broad, flat valley, Stony creek one mile; and Payette creek four miles. The valley of the east branch is connected in places with Martin creek by a gravel plain.

\section{DRAINAGE}

One large tributary, the east branch, which joins the main river below the area examined, and four other large creeks with their tributaries, make up the drainage system. The general course of the secondary system is from northwest to southwest, on the higher levels the drainage is interrupted, giving rise to small swamps and lakes.

\section{HISTORY OF TREATMENT}

The cutting of pulpwood from the two townships began in 1905 and was continued until 1914 , the heaviest cutting being made during the period 1908 to 1910 inclusive. Owing to the cut being done both from company camps and by jobbers, and to the practice of cutting by the piece and by the cord areas on which any particular system of cutting was used, cannot be segregated.

About thirteen years previous to the date of the first study, several sections were burned in the southern and eastern parts of the area; while a fre covering 1,800 acres extending up the main river and into the former burn on the east branch occurred in 1920 when the survey party was on the ground.

\section{DEFINITION OF TYPES}

The original scheme of type classification laid down in the 1920 survey was followed in the second survey as closely as possible.

Three types were recognized, softwood, mixed-wood and hardwood. Those stands of which seventy-five per cent. of the volume were composed of conifers were called softwood; those with seventy-five per cent hardwood wrere placed in the hardwood type; the remainder were called mixed. wood. However, since the study of growth in the first survey was confined to the pulpwood species, spruce and balsam fir, the growth of the hardwoods in the softwood and mixedwood types as well as all growth in the hardwood type are not being dealt with here.

\section{NUMBER OF TREES PER ACRE}

The following table summarizes and compares the number of trees of spruce and balsam fir of the softwood type in the jvarious diameter classes at the two dates of measurement. 
TABLE NO. 1

SOFTWOOD TYPE

Comparison of Numbers of Trees Per Acre

In 1920 and 1927

\begin{tabular}{|c|c|c|c|c|c|c|}
\hline \multirow{2}{*}{$\begin{array}{l}\text { D.B.H. } \\
\text { Inches }\end{array}$} & \multicolumn{2}{|c|}{ Spruce } & \multicolumn{2}{|c|}{ Balsam } & \multicolumn{2}{|c|}{ Totals } \\
\hline & 1920 & 1927 & 1920 & 1927 & 1920 & 1927 \\
\hline 1 & 25.58 & 36.8 & 62.64 & 138.6 & 88.22 & 175.4 \\
\hline 2 & 13.29 & 24.9 & 36.16 & 73.7 & 49.45 & 98.6 \\
\hline 3 & 10.24 & 14.1 & 27.78 & 35.7 & 38.02 & 49.8 \\
\hline \multicolumn{7}{|l|}{ Sub- } \\
\hline Total & 49.11 & 75.8 & 126.58 & 248.0 & 175.69 & 323.8 \\
\hline 4 & 7.28 & 9.3 & 16.35 & 25.5 & 23.63 & 34.8 \\
\hline 5 & 5.49 & 7.2 & 14.22 & 19.3 & 19.71 & 26.5 \\
\hline 6 & 5.35 & 5.6 & 11.38 & 14.1 & 16.73 & 19.7 \\
\hline 7 & 3.89 & 5.2 & 8.77 & 9.4 & 12.66 & 14.6 \\
\hline 8 & 3.23 & 3.9 & 6.62 & 7.7 & 9.85 & 11.6 \\
\hline 9 & 2.25 & 3.6 & 4.16 & 4.7 & 6.41 & 8.3 \\
\hline 10 & 1.35 & 1.9 & 2.51 & 2.3 & 3.86 & 4.2 \\
\hline 10 & 1.95 & 3.7 & 1.65 & 2.6 & 3.60 & 6.3 \\
\hline \multicolumn{7}{|l|}{ Sub- } \\
\hline & & 40.4 & 65.66 & 85.6 & 96.45 & 126.0 \\
\hline \multicolumn{2}{|c|}{$\begin{array}{l}\text { Main stand } \\
\text { difference }\end{array}$} & \multicolumn{2}{|c|}{9.6} & 20.0 & \multicolumn{2}{|c|}{29.5} \\
\hline Totals & 79.90 & 116.2 & 192.24 & 333.6 & 272.14 & 449.8 \\
\hline \multicolumn{7}{|l|}{ Total } \\
\hline differen & & 36.3 & & 141.4 & & \\
\hline
\end{tabular}

During the seven year interval many seedlings of less than 0.6 inch D.B.H. in 1920, have grown into the measurable stand, and at the same time the other trees have entered the higher diameter classes. It may be assumed that all of the trees in the one-inch class in 1927 are newcomers since 1920; whether some of the trees in the two-inch class are newcomers also depends on whether their growth in the seven-year period exceeds 1.0 inch, and how close they were to the lower limit of the one-inch class (0.6 inch) in 1920. It is significant that the total increase in number of trees (178) is practically equivalent to the number of trees in the oneinch class in 1927, (175) from which it may be inferred that mortality during the interval was negligible, 
TABLE NO. 2

Mixedwood Type

Comparison of Number of Trees Per Acre

In 1920 and 1927

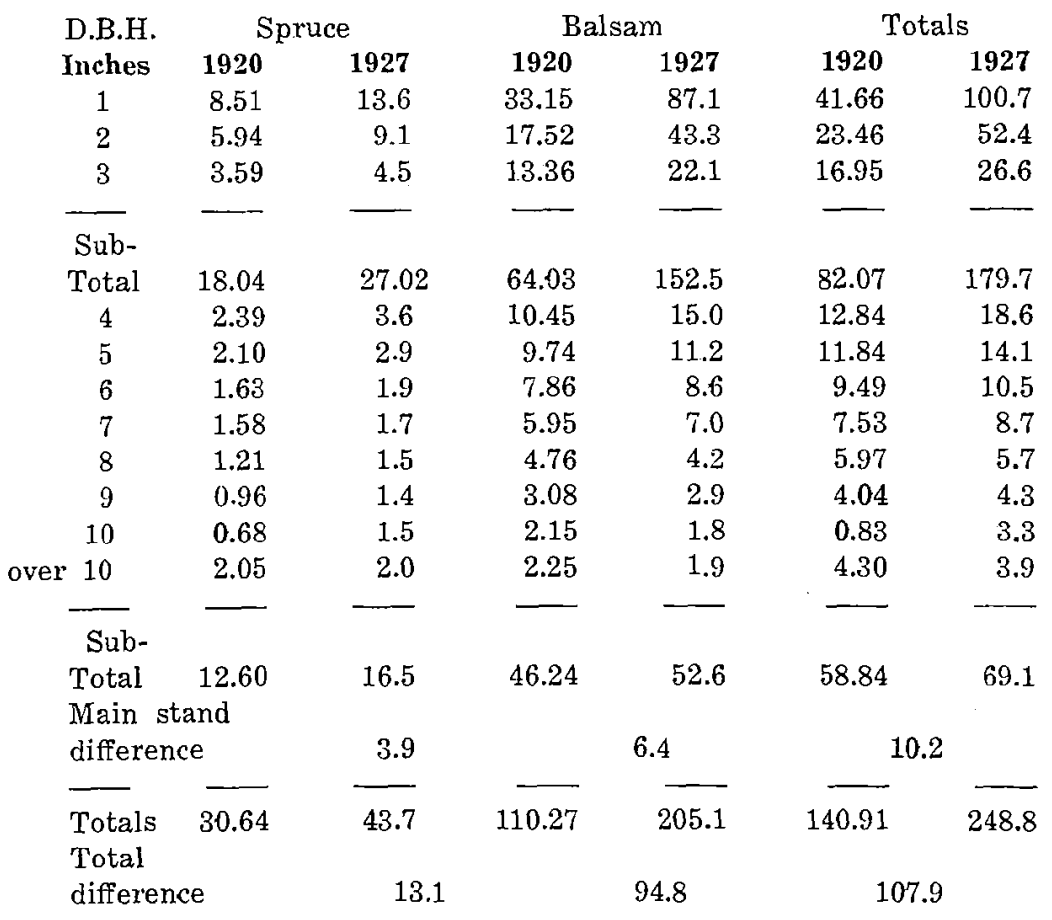

Again as with the softwood type, it is apparent that the stand averages under investigation are the same for both periods since the total increase in numbers is 108 trees while the trees entering the one-inch class is 101 trees. The minor discrepancy may be due to variation in sampling or to mortality.

\section{VOLUMES OF SPRUCE AND BALSAM FIR}

In calculating the volumes, the curves as used in 1920 were used again in 1927 notwithstanding that form-class volume tables had become available in the interval, since it was impractical to recalculate the original data on the F.C. basis.

The following table shows the volumes in cubic feet of spruce and balsam in the softwood type in 1920 and in 1927 as well as the increment during the period. 
TABLE NO. 3

SOFTWOOD TYPE

Total Volumes of Spruce and Balsam Fir Per Acre Spruce Balsam Fir

$\begin{array}{ccccc}\text { D.B.H. } & 1920 & 1927 & 1920 & 1927 \\ \text { Inches } & \text { Cu. Ft. } & \text { Cu. Ft. } & \text { Cu. Ft. } & \text { Cu. Ft. } \\ 1 & 5.1 & 7.4 & 12.5 & 27.7 \\ 2 & 5.3 & 10.0 & 28.9 & 59.0 \\ 3 & 7.2 & 9.9 & 37.3 & 46.4 \\ 4 & 9.3 & 13.9 & 35.1 & 51.0 \\ 5 & 14.8 & 19.4 & 45.0 & 57.9 \\ 6 & 23.5 & 24.6 & 52.4 & 64.9 \\ 7 & 25.2 & 33.8 & 57.1 & 61.1 \\ 8 & 29.5 & 35.5 & 59.6 & 69.3 \\ 9 & 27.0 & 43.2 & 48.6 & 55.0 \\ 10 & 20.9 & 29.4 & 37.3 & 34.0 \\ 11 & 15.7 & 37.0 & 15.0 & 20.0 \\ 12 & 12.6 & 14.3 & 11.3 & 21.7 \\ 12 & 23.1 & 43.0 & 0.9 & 15.5 \\ \text { over } & 219.2 & 321.4 & 441.0 & 583.5 \\ \text { Total } & & 102.2 & & 142.5 \\ \text { Increment (7 years) } & 14.6 & & 20.3\end{array}$

It may be seen from an examination of tables Nos. 1 and 3 that the stand of 272 spruces and balsam fir increased to 450 trees in seven years, a rate of 7 per cent. The volume increment was from 660 cubic feet to $90 \tilde{5}$ cubic feet, or 4.7 per cent., the difference in rate being due to the fact that the increase in number was in the one-inch class.

In terms of cords ( 90 cubic feet per cord) the stand of approximately 7 cords in 1920 increased to 9 cords in 1927, a rate of about one third cord per year.

A comparison of the two species shows that the spruce stand of 219 cubic feet increased 102 cubic feet at a rate of 14.6 cubic feet per year, or 5.4 per cent. The balsam fir stand of 441 cubic feet increased 142 cubic feet or 203 cubic feet per year, a rate of 3.9 per cent., which indicates that the relative position of spruce is improving. 
TABLE NO. 4

\section{MIXEDWOOD TYPE}

Total Volumes of Spruce and Balsam Per Acre

\begin{tabular}{ccccc} 
& \multicolumn{2}{c}{ Spruce } & \multicolumn{2}{c}{ Balsam Fir } \\
D.B.H. & 1920 & 1927 & 1920 & 1927 \\
Inches & Cu. Ft. & Cu. Ft. & Cu. Ft. & Cu. Ft. \\
1 & 1.7 & 2.7 & 6.6 & 17.4 \\
2 & 2.4 & 3.6 & 14.0 & 34.6 \\
3 & 2.4 & 3.1 & 17.0 & 28.7 \\
4 & 3.6 & 5.4 & 21.9 & 30.0 \\
5 & 5.6 & 7.8 & 30.4 & 33.6 \\
6 & 7.2 & 8.4 & 36.1 & 39.6 \\
7 & 10.3 & 11.0 & 38.8 & 45.5 \\
8 & 11.0 & 13.6 & 42.6 & 37.8 \\
9 & 11.5 & 16.8 & 36.0 & 33.9 \\
10 & 10.6 & 23.2 & 31.9 & 26.6 \\
11 & 11.0 & 9.7 & 21.4 & 20.0 \\
12 & 10.9 & 11.9 & 13.3 & 4.3 \\
over 12 & 37.2 & 48.9 & 10.9 & 17.5 \\
Total & 125.4 & 166.1 & 320.9 & 369.5 \\
Increment (7 years) & 40.7 & \multicolumn{3}{c}{48.6} \\
Annual Increment & 5.8 & \multicolumn{3}{c}{6.9}
\end{tabular}

Tables Nos. 2 and 4 dealing with the mixedwood types may be compared as were Tables Nos. 1 and 3. The mixedwood stand contained 141 spruce and balsam fir in 1920, increasing to 249 trees, a rate of 8.0 per cent. In volume the increment is from 446 to 536 cubic feet, or 12.7 cubic feet per year, a rate of 2.6 per cent. In cords the stand of approximately five cords increased to six cords in 1927, about one seventh of a cord per acre per year.

If only those trees above 3 inches in diameter be considered, there are at present 8:3 cords per acre in the softwood type growing at the rate of 25.8 cubic feet or 0.29 cord per acre per year. In the mixedwood type there are nearly five cords per acre of the two pulpwood species which are growing at the rate of only 6.2 cubic feet per acre per year (or 0.7 cord).

Thus it is seen that while in the softwood type most of the increment is on the material four inches and over, as would be expected, in the mixedwood type the small amount of increment is mostly on the saplings. This is also to be expected since in the mixedwood type with the removal of nearly all the spruce and balsam fir of pulpwood size the competition of the hard. woods is greatly increased.

\section{PROPORTION OF SPRUCE}

The two surveys of the same area provide some added data on the muck. discussed question of whether under the present method of cutting the spruce 
will hold its own against the more readily reproduced balsam fir in our cut-over pulpwood lands. The following table shows the percentage of spruce in relation to balsam fir in number of trees and volume, at the two dates of survey.

TABLE NO. 5

Percentage Relation of Spruce to Balsam Fir SOFTWOOD TYPE

Number of Trees Total stand Miain stand Volume

Total stand

Main stand

Number of Tres Total stand

Main stand Volume

Total stand

Main stand

1927
Percent
Spruce

Percent

Spruce

$\begin{array}{ccc}29 & 26 & -3 \\ 29 & 30 & +1 \\ & & \\ 33 & 35 & +2 \\ 36 & 39 & +3\end{array}$

MIXEDWOOD TYPE

$\begin{array}{lll}22 & 18 & -4 \\ 21 & 24 & +3 \\ 28 & 31 & +3 \\ 30 & 35 & +5\end{array}$

It will be noted in this table that in all cases except the number of trees in the total stand which include the 1,2, and 3-inch classes, the proportion of spruce in relation to balsam fir has been increasing. It is also demonstrated that although a large number of balsam fir in the 1,2 and 3-inch classes enter the stand more of the spruce in these diameter classes survive to reach the higher diameter classes than do the balsam. Hence it would seem that the prediction that spruce will form at least fifty per cent of the volume of the pulpwood species in the softwood type and 40 per cent in the mixedwood type at the time of the next cut is not unduly optimistic.

\section{REGENERATION}

In the course of each of the surveys a tally of the number of seedlings of spruce and balsam fir was made on small plots uniformly distributed throughout the area. The following table shows the number of seedlings per acre at the two dates of measurement.

TABLE NO. 6

Spruce and Balsam Fir Seedlings

Number Per Acre

SOFTWOOD TYPE

Date

1920

1927

Spruce

179

266

MIXEDWOOD TYPE

1920

1927

222
63

Balsam

731

900

496

482 
The number of spruce seedlings in the softwood type have increased 49 per cent. while balsam fir have only increased 23 per cent during the seven year period, although in actual numbers the increase was 87 spruce and 169 balsam fir per acre.

In the mixedwood type, however, there are less spruce and balsam fir scedlings than there were seven years before. Although the representation of balsam fir has only slightly decreased, there has been a very great falling off in the spruce only about one quarter the number present at the beginning of the period being present in 1927.

These data would indicate that conditions are much better for the regeneration of the pulpwood species in the softwood than in the mixedwood type. Spruce has responded more noticeably than balsam fir to the conditions obtaining (favourable in softwood, unfavourable in mixedwood type). However, it should be noted that in the mixedwood main stand growth factors favor spruce (the growth rate for spruce is 4.2 , for balsam fir 2.1 per cent) so that the unfavorable growth conditions for spruce seedlings in the mixedwood type may not predicate unfavourable conditions when the trees finally reach the main stand.

\section{SUMMARY}

The information obtained from the survey may be summarized as follows:

1. In the softwood type cut-over lands of the Goulais district there are at present 3.3 cords of spruce, 5.0 cords of balsam fir, or 8.3 cords of pulpwood $4 "$ D.B.H. and over per acre.

2. In the mixedwood type there are 1.7 cords of spruce, 3.2 cords of balsam fir, or 4.9 cords of pulpwood per acre.

3. The increment of pulpwood species, total stand, softwood type is 0.35 cord; of material 4" D.B.H. and over 0.29 cord per acre per year.

4. In the total stand of mixedwood type it is 0.14 cord; or of material $4 "$ and over 0.06 cord.

5. Spruce is not only holding its own in relation to balsam fir, but has increased its proportion of the pulpwood species both in the softwood and the mixedwood type.

6. Conditions for establishment and growth of coniferous seedlings have improved in the softwood type, but have become worse in the mixedwood type. 